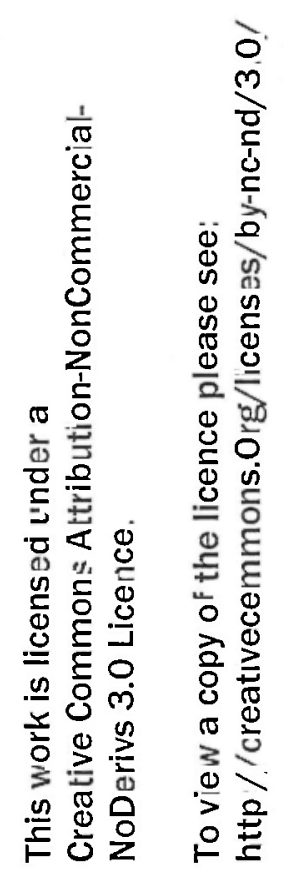


prined from The Journal of Political Econosy

Repr. LXXIII. No. 5, October 1965

Copyright $\{55$ by the University of Chicago

Printed in U.S.A.

\title{
TOWARD A GENERAL THEORY OF CUSTOMS UNIONS FOR DEVELOPING COUNTRIES
}

\author{
C. A. COOPER AND B. F. MASSELL ${ }^{1}$ \\ RAND Corporation, Santa Monica, California \\ and \\ Centre for Economic Research, Nairobi, Kenya
}

$\mathrm{D}$ URING the past fifteen years, economists have constructed an impressive theoretical apparatus for viewing the effect on a group of economically advanced nations of forming a customs union (CU). But there is no comparable body of analysis dealing ; with customs unions among less developed countries. To an important degree, such a theory must focus on economies of scale, changes in the terms of trade, balance of payments problems, externalities, capital imports, and underemployment-factors that have received isolated treatment in the literature but that have not been successfully woven into an integrated analytical framework. However, before one can construct a general model that takes these "dynamic" factors into account, it is useful to lay a foundation whose blocks are the ordinary static efficiency considerations dealt with in the $\mathrm{CU}$ literature relating to developed countries.

A fundamental difficulty in building on existing theory as developed by Viner, Meade, Lipsey, and others, ${ }^{2}$ relates to what may be regarded as a dilemma of CU theory. Except for the terms-oftrade argument, ${ }^{3}$ the very grounds on which a $\mathrm{CU}$ is said to be superior to nondiscriminatory protection are precisely those grounds on which the union is necessarily inferior to free trade. A "good" $\mathrm{CU}$ is one that raises income

${ }^{1}$ The authors are indebted to Ricliard N:Cooper and Harry G. Johnson for theil velWbielbfulTdomments. through trade creation - that is, a move toward free trade. A "bad" union, on the other hand, reduces income through trade diversion-that is, a more protectionist policy. But, if a country accepts a "good" union as desirable, why does it not move all the way to free trade? And conversely, if a country is willing to reject the full benefits of free trade for the sake of unilateral protection, why should it be willing to give up its sheltered industries for the partial benefits of a CU? These questions are not dealt with systematically in the literature. ${ }^{4}$

${ }^{2}$ See Jacob Viner, The Cusloms Union Issue (New York: Carnegie Endowment for International Peace, 1950); James E. Meade, The Theory of Customs Unions (Amsterdam: North-Holland Publishing Co., 1955); Richard G. Lipsey, "Trade Diversion and Welfare," Economica, XXIV (February, 1957), 4046, and "The Theory of Customs Unions: A General Survey," Economic Journal, LXX (September, 1960), 496-513; John Spraos, "The Condition for a Trade-Creating Customs Union," Economic Journal (March, 1964), pp. 101-8; Bela Balassa, The Theory of Economic Inlegration (Homewood, Il1. : Richard D. Irwin, 1961).

${ }^{3}$ We have ruled out terms-of-trade effects in this paper for three reasons: (1) They are probably not an important source of gain from economic integration among a group of less developed countries. (2) In those cases where a terms-of-trade effect is important (for example, the European Economic Community), it is not especially interesting to evaluate a $\mathrm{CU}$ without considering also the effects of retaliation by those excluded from the club. (3) Our concern here is with the pure (static) theory of CU's among less developed countries; it is convenient to simplify the analysis as far as possible.

"We have discussed this issue elsewhere; see our "A New Look at Customs Union Theory" (Santa Monica, Calif.: RAND Corporation, P-2972-2, April, 1965).

\section{DEVELOPMENT $4 \mathbf{6} 1$}

STUDIES

L!: ARY 
This issue is especially relevant to the analysis of a CU formed by less developed countries. Whereas existing CU theory is, essentially, a disguised argument for free trade, what is needed is an analysis of alternative policies of protection. The mere fact that preunion protection exists suggests that free trade is not viewed as desirable by many countries, notably by a majority of the less developed countries. Although present CU theory leads to the conclusion that a world-wide union would be optimal, few of these countries would accept this view. Indeed, a principal objective of economic integration among less developed countries is to foster industrial development and to guide such development along more economic lines. Yet, the considerations that lead such a country to favor economic integration and to prefer one country to another as a prospective union partner lie outside traditional analysis. For example, what insight does CU theory provide regarding whether Mexico would be anxious to form a $\mathrm{CU}$ with the United States? Would trade creation provide Mexico with a welfare gain? Or would the blow to Mexican industry more than offset any rise in non-industrial income?

Just as increases in protection may have their cost, so may decreases in protection. Protection is justified, or rationalized, on many grounds, political as well as economic. It can be used to alter a country's terms of trade, to increase domestic employment, to raise revenue, or to foster local industry. It is certainly true that many less developed countries have accepted the arguments put forward by Prebisch, Seers, and others, in support of an accelerated industrialization policy. ${ }^{5}$ Much of the work of the United Nations Economic Commission for Latin America and the Economic Commission for Africa, for example, is concerned with outlining such a policy.

The present study attempts to lay a cornerstone for a more general theory of CU's in less developed countries. We do not attempt to examine the conditions under which a protectionist policy makes good sense; rather, we accept industrialization as a legitimate policy goal and consider how membership in a CU may enable a less developed country to achieve more economically the ends served by protection. We emphasize, again, that we do not attempt here the complete dynamic theory that must ultimately form the basis for decisionmaking. ${ }^{6}$ Our objective is the more modest one of weaving together into a single analytical strand the fragments relating to the static impact of a CU.

\section{PREFERENCE FOR INDUSTRY}

Our analysis is based on the simple assumption that there may be a social preference for particular types of economic activity-which we shall call "industry"-compared with other forms of activity. Specifically, we assume that economic planners in a less developed country may be willing to accept some reduction in national income to achieve an increase in industrial production. ${ }^{7} \mathrm{In}$ -

'See Raul Prebisch, "Commercial Policy in the Underdeveloped Countries," American Economic Review, XIIX (May, 1959), 251-73; Dudley Seers, "A Model of Comparative Rates of Growth in the World Economy," Economic Journal, LXXIII (March, 1962), 45-78.

${ }^{6}$ Some elements of a dynamic theory of less developed countries are contained in Sidney Dell, Trade Blocs and Common Markets (New York: Alfred A. Knopf, 1963); R. S. Bhambri, "Customs Unions and Underdeveloped Countries," Economia Internazionale, XV (March, 1962), 235-58; Massell, "The Distribution of Gains in a Common Market" (in preparation).

${ }^{7}$ Throughout this analysis we shall identify social choice with the choice of the national economic planners. It is important to note that their concern is with the choice between industrial and other types 
dustrial production must, therefore, be introduced as a new dimension of the analysis. To compare alternative production possibilities, not only the national income but also the level of industrial production associated with each must be taken into account. This is shown in Figure 1 by the planners' "demand" curve, $D D^{\prime}$, which expresses the "price" (in terms of national income foregone) ferent to a choice between any two different industries and that diversification within the industrial sector is not an objective. $^{8}$ Therefore, the planners satisfy their demand for industrial production by selecting the lowest cost industries.

The "supply" side in Figure 1 is represented by the stepped curve $S S^{\prime}$. To simplify the exposition, we assume full employment, constant costs, competitive

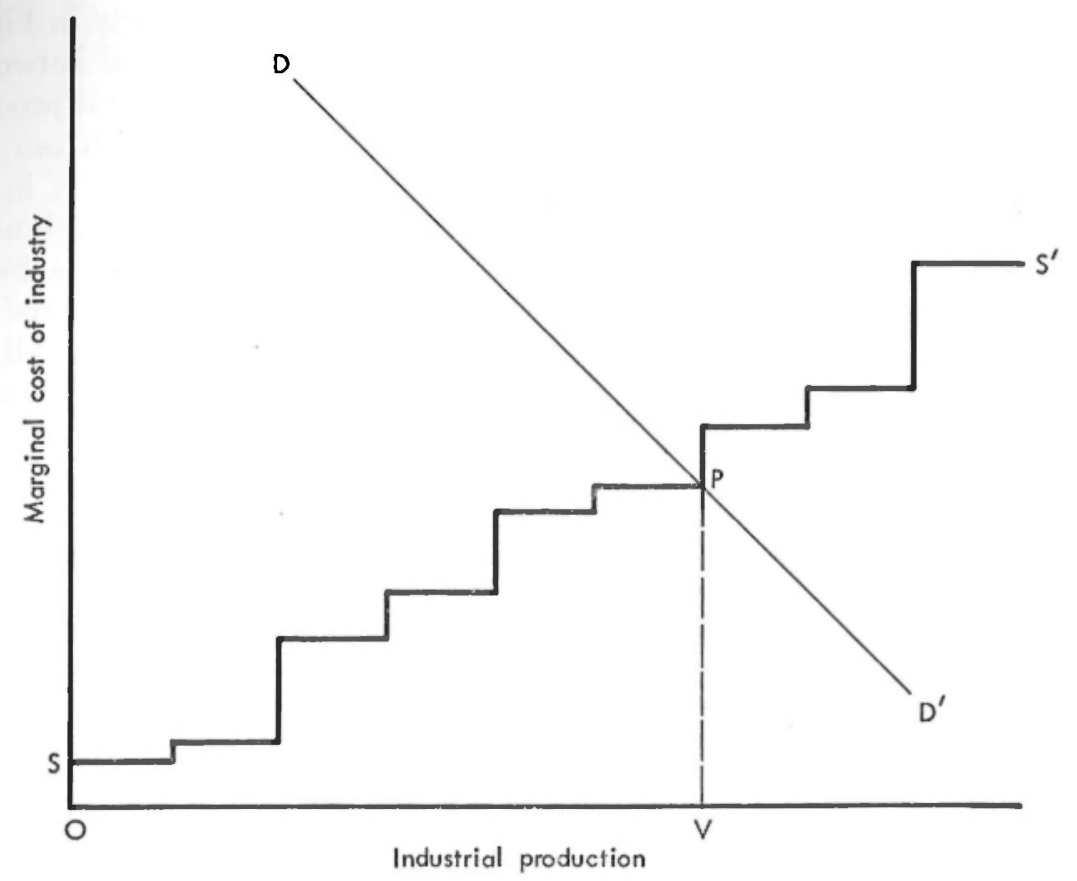

Fic. 1.-Demand for industry

that planners are willing to pay for each increment to industrial production. It is assumed that, at a higher price, planners will typically choose less protection. It is further assumed that planners are indif-

of economic aclivily (or, equivalently, between industrial activily and national income). They are indifferent with respect to how consumers spend their income. Note also that we do not assume that planners do prefer industry, only that they may. The limiting case, where planners have no preference for industry, is discussed briefly in the text below. pricing, and constant terms of trade. ${ }^{9}$ Consider that initially only a single agricultural export good (corn) is produced and that corn production is more profitable in this country than any other economic activity. It is cheaper to import

${ }^{8}$ The model can be generalized easily to take these factors into account, but the exposition becomes cumbersome.

9 These assumptions are in the spirit of existing CU theory. 
all other goods in exchange for corn exports than to produce them locally. The average "cost" of a local industry is then defined as the amount by which the average cost of producing the industry's output exceeds the price of a comparable imported good. ${ }^{10}$ This cost is a measure of national income foregone by producing each unit of the good, where income is measured in purchasing power at worldmarket prices. It is assumed that industries under consideration by the planners are separable-that production in one does not require the presence of another, either as a market or as a source of supply.

To obtain the supply-of-industry (hereinafter referred to as "supply") curve, industries are ranked in ascending order according to their cost. As all industry is by assumption uneconomic and only corn is exported, ${ }^{11}$ domestic demand places a constraint on the level of production in each industry. As a result, an expansion in industrial output involves moving up the steps in the curve, each step corresponding to a successively higher-cost industry. ${ }^{12}$

The optimal level of industrial production, as determined by the intersection of the demand and supply curves, is $O \mathrm{~V}$ in Figure 1. Corresponding to this level of industrial production is an efficient tariff, ${ }^{13}$ that is, a set of tariff rates that provide enough protection in each industry to the left of $V$ to induce local production in that industry and that provide no protection for industries to the

${ }^{10} \mathrm{By}$ assumption, all industries have a cost greater than zero.

II We shall discuss export subsidies later in the text; for now, they are ruled out.

${ }_{12}$ In Fig. 1 the steps have been drawn the same $=$ length. This need not be the case but was done for ease of exposition-see text below. Note that the diagram ignores any changes in quantities consumed that may result from the adverse income effects to consumers of increased protection. right of $V$. With constant costs, indus. tries either supply the entire domestic market or do not operate at all. An industry will operate if (and only if) protected by a tariff rate no lower than the industry's cost. ${ }^{14}$ In Figure 1, VP is the marginal cost of protection to the economy, that is, the cost of protecting the marginal industry. The total cost of protection is the area OSPV.

The welfare implications of this analysis can be seen more clearly in Figure 2. The technological trade-off between national income and industrial production is described by $M N$, which can be derived from the supply curve $\mathrm{SS}^{\prime}$ in Figure 1. Curve $M N$ shows how much national income must be foregone to achieve alternative levels of industrial production, subject to the constraint that all industrial production is consumed domestically. We shall term this curve a production-consumption locus. ${ }^{15}$ Moving down curve $M N$ corresponds to moving up the hierarchy of industries and increases the marginal cost of protection in discrete steps. Thus $M N$ is stepwise convex. At point $N$, the economy would be producing only industrial goods, all for domestic consumption. National income would then equal industrial production. Under the present assumptions, then, $M N$ cannot cross the $45^{\circ}$ ray from the origin.

${ }^{13}$ Throughout the paper, we use the term "tariff" as shorthand for a set of tariff rates, one for each industry (some of which may be zero). Note also that we are focusing on polential gains; whether these gains are realized depends, of course, on whether an appropriate tariff is actually chosen.

14 With constant costs, a protective tariff on a particular industry's product is either ineffective or prohibitive. Provided the tariff is prohibitive, because of assumed competitive pricing it makes no difference how high the tariff rate is raised.

${ }^{15}$ The production-consumption locus is not to be confused with either a production-possibilities or a consumption-possibilities locus; in a sense, it is a blend of the two. 
The indifference curve $I I^{\prime}$ in Figure 2 expresses the planners' preference for industrial production and is related to the demand curve $D D^{\prime}$ in Figure $1 .{ }^{16}$ If planners were indifferent between producing corn and industrial goods, the indifference curve would be horizontal,

\section{SPECIALIZATION AND EFFICIENCY}

Now consider two countries, North and South, each with a development plan that consists simply of a list of industries to be developed during the plan period. Assume, for expository convenience, that the domestic demand is the

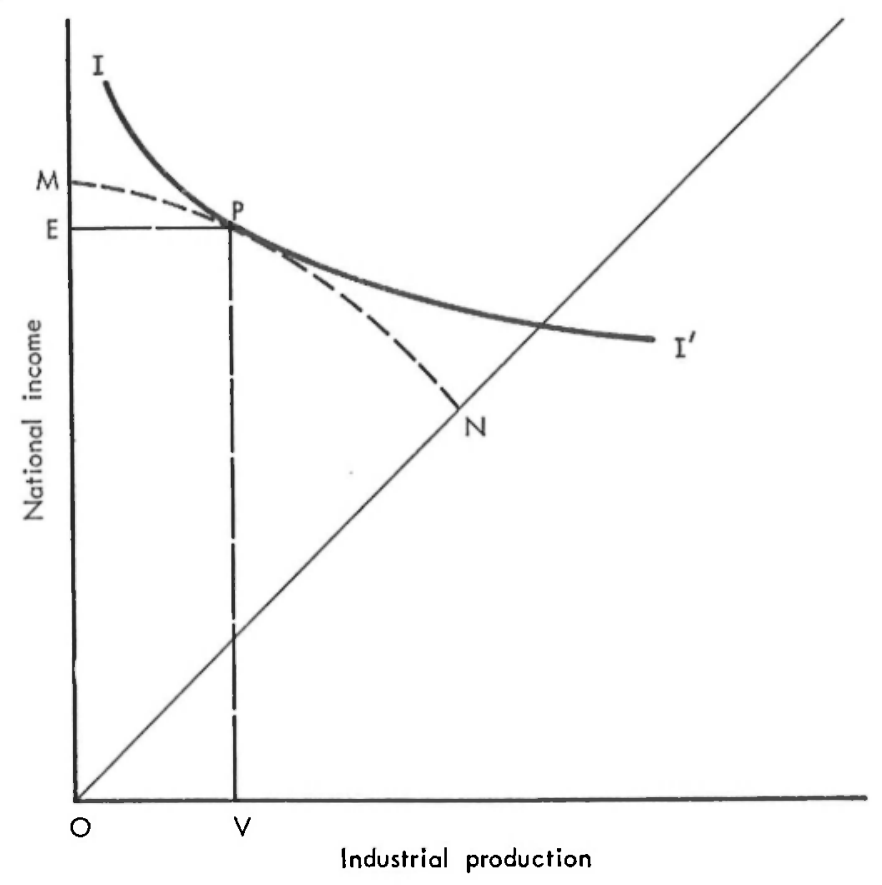

FIG. 2.-Preference for industry

providing a corner optimum at point $M$, with all of the economy's resources devoted to corn production. With a negatively sloped indifference curve, as shown in Figure 2, the optimal position is at point $P$ and includes a mixture of $O V$ industrial goods and corn output equal to $O E-O V$.

${ }^{16}$ If the planners' demand for industry is income elastic, the demand curve in Fig. 1 will shift to the right if $M N$ shifts up. Strictly speaking, therefore, we should begin with the analysis contained in Fig. 2 and then derive the Fig. 1 results. But for clarity of exposition, it appears better to proceed as we have. same for each industrial product and is equal in the two countries. ${ }^{17}$

Next, consider the formation of a CU between North and South. As contrasted with a common market, a $\mathrm{CU}$ does not permit a free flow of resources between member countries. But, while resources are not pooled, markets are; and the pooling of markets permits specialization. Unless the two countries have iden-

${ }^{17}$ Then the steps in Fig. 1 are all of the same length. Moreover, the steps in one country's supply curve are the same length as those in the other country's curve. 
tical economic structures, they will be able to produce a given level of combined industrial output at a lower cost in terms of income foregone.

The level of industrial production, its composition, and its distribution between the two countries is fully determined by a common external tariff ${ }^{18}$ that is, a set of tariff rates, one for each item. In principle, any tariff can be chosen. Thus the level, composition, and (within limits) ${ }^{19}$ distribution of industrial production is subject to manipulation by the economic planners. For this reason it is of little interest to ask whether a $\mathrm{CU}$ is "good" or "bad" without specifying the tariff to be chosen. The question to which the present paper is principally addressed can now be formulated: Is there any tariff that will make both countries better off relative to individually optimal policies of non-preferential protection?20

One class of tariffs that deserves consideration is the set of "efficient" tariffs, where an efficient tariff is defined as one that provides any specified level of industrial production in the $\mathrm{CU}$-irrespective of the composition and distribution of this production-at the lowest cost in terms of combined national income foregone by the two countries.

The gains from specialization, under assumed tariff efficiency, can be seen in Figure $3 a$. The curves $S_{n}$ and $S_{s}$ represent the supply curves for North and South, respectively, before forming the $\mathrm{CU}$. With the $\mathrm{CU}$, there is a new hierarchy of industries for the $\mathrm{CU}$ as a whole;

18 To avoid cumbersome phases, we shall refer to the common external tariff in a CU as simply the "tariff."

${ }^{19}$ The "limits" will become clear presently.

${ }^{20} \mathrm{~A}$ limiting case of which is free trade. There may be more than one such tariff, in which case we are also faced with the problem of choosing from among a set of tariffs. See text below. corresponding to this hierarchy is a new supply curve, $S_{u}$. The new supply curve will lie below the old curves for two reasons. ${ }^{21}$ First, if any item is produced at all in the CU, it will be produced in the lower-cost country;22 second, the lowest cost industries can be operated at twice the pre-CU level of output (to supply both markets), so that any given level of industrial production can be obtained without resort to the higher-cost industries. There is an efficient tariff corresponding to each point on the combined supply curve. Industries to the left of that point are protected; industries to the right are not.

The tariff that is chosen will depend on the preferences of the planners in the two countries. If the planners are indifferent as to the distribution of industrial production between the countries, they will choose an efficient tariff. ${ }^{23}$ The initial lists contained industries that the planners were willing to pay for. In the CU, planners can obtain satisfaction more efficiently by pooling markets. There is, consequently, an income effect; the countries can produce the same combined industrial output with the $\mathrm{CU}$ that was planned initially and will have resources to spare. The income effect will tend to lead to an increase in both industrial production and national income. There is also a substitution effect, due to the lower marginal cost of protection, which will lead to an increase in industrial pro-

\footnotetext{
${ }^{21}$ Assuming $S_{n}$ and $S_{s}$ not to be horizontal.

${ }^{22}$ That is, the country with the intra-union comparative advantage.
}

${ }^{23}$ We have already assumed planners to be indifferent with respect to the composition of the industrial sector. Indifference with respect to the distribution between countries can be visualized most easily in terms of the formation of a joint economic planning board with responsibility for the economic development of the $\mathrm{CU}$ as a whole (although, in practice, even such a board is always subject to pressures from each of the countries). 
duction at the cost of national income. Both effects will combine to increase industrial production; national income will increase as well, if the income effect outweighs the substitution effect.

As an example of the gains, consider that, in Figure $3 a$, each country initially planned industrial production equal to $O M$, so that planned industrial production of the two countries combined was equal to $O P$. North planned to produce shoes and hats, and South planned to produce coats and shirts. With a CU, the same combined industrial production,
$O P$, can be obtained at a lower cost by producing twice as many shoes and coats and by foregoing production of highercost hats and shirts.

It may be more realistic to drop the assumption that planners are indifferent to the distribution of gains between countries, and to assume instead that planners in each country are primarily or solely interested in gains to that country. ${ }^{24}$

${ }^{24}$ As countries are decision-making units, it is important that each member country is convinced that it gains from joining the $\mathrm{CU}$; otherwise it can refuse to join.
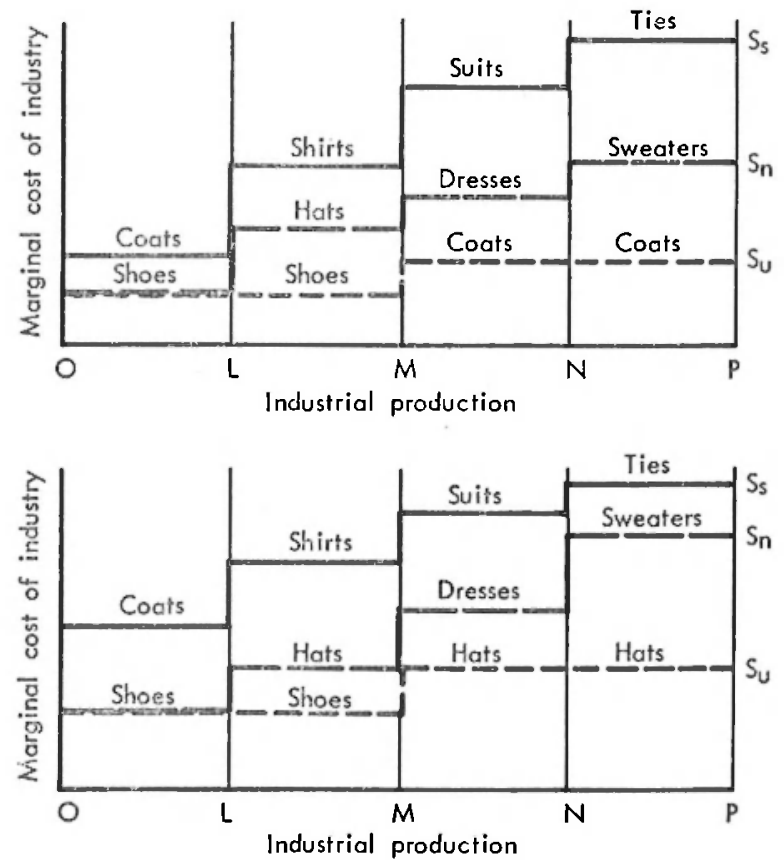

(b)

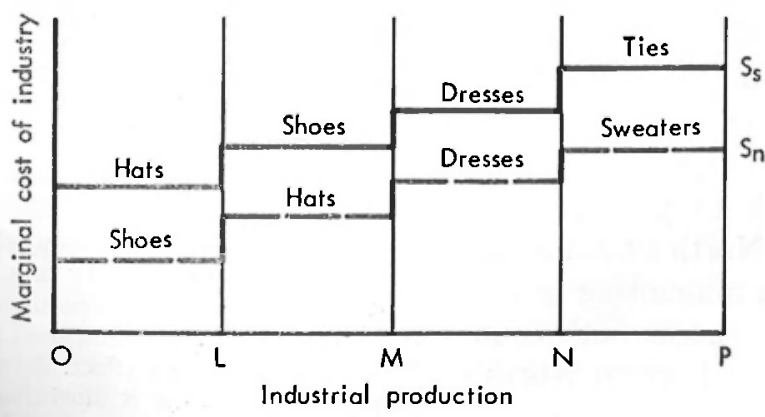

(c)

FIG. 3,-Effects of specialization 
Each country's level of social welfare (as reflected by the planners' indifferencecurve map) is determined by that country's level of industrial production and income and is, therefore, completely specified by a common external tariff, together with a rule for distributing income between the countries.

If the tariff and the rule for distributing income are chosen by the two planning boards in collaboration, and if the two groups of planners act rationally, ${ }^{25}$ they will choose a tariff and a rule that jointly result in a Pareto-optimal situation, that is, that result in a pair of levels of industrial production and national income such that neither country's social welfare can be increased without decreasing the social welfare of the partner country. But, as the following example illustrates, an efficient tariff may be nonPareto optimal for any distributive rule.

Figure $3 b$ is similar to Figure $3 a$, except that North's hat industry is now cheaper than South's coat industry. If, as before, combined industrial production is to be equal to $O P$, then an efficient tariff will protect shoes and hats, both of which will locate in North. North gets twice as much industry with the $\mathrm{CU}$ than without, but South gets no industry at all.

Now, make the further illustrative assumption that the planners' demand curve in each country is a vertical line passing through point $M$. Then South will willingly give up an arbitrarily large amount of income to obtain industrial production equal to $O M$. For South to reach this position with an efficient tariff requires North to produce both shoes and hats, with North's total industrial production then amounting to $O P$. North's hat industry causes both countries an income loss and, given North's

${ }^{25}$ As we assume throughout the analysis. planners' demand curve, there is no commensurate gain. Then, whatever the distribution of income between the two countries, this efficient tariff is nonPareto optimal. The welfare of both countries could be raised by eliminating North's hat production. There is no efficient tariff that will enable each country to produce exactly $O M$ units of industrial output. ${ }^{26}$

By considering only efficient tariffs one throws away degrees of freedom. The level of the tariff can be changed, and income can be redistributed between the countries; but industrial production cannot be redistributed. Additional degrees of freedom can be gained by considering a wider class of tariffs. And, as we shall see below, still more freedom can be obtained by considering either a partial $\mathrm{CU}$ or subsidization.

\section{QUASI-PARETO OPTIMALITY}

Given a national preference for industry, the evaluation of the impact of a $\mathrm{CU}$ on a member country must take into account not only changes in the country's national income but also changes in the size of the country's industrial sector. A gain in either dimension, if offset by a sufficiently large loss in the other dimension, will render the economy worse off. It is not sufficient to look at the joint income of the participants; to assess the welfare effects of a $\mathrm{CU}$ requires examining the two indifference-curve maps.

Sepcifying a common external tariff determines the level of industrial production in each country and the joint national income. But, because there is scope

\footnotetext{
${ }^{26}$ In this situation the only efficient tariff that results in Pareto optimality is a tariff protecting shoes only. But then the gains all go to North. Compensation (in the form of income) paid by North to South would have no effect. Admittedly, this example is extreme, but it illustrates a more general point about tariff efficiency, as defined here.
} 
for redistributing this income without changing the tariff, the income of each country is not specified. Now, let us define a quasi-Pareto-optimal tariff as a tariff with the following property: Given the level of industrial production in each country, joint national income is maximized.

An efficient tariff is necessarily quasiPareto optimal, but not all quasi-Paretooptimal tariffs are efficient. An example of an inefficient quasi-Pareto-optimal tariff can be seen in Figure $3 b$; as noted above, an efficient tariff corresponding to joint industrial production of $O P$ is one that protects shoes and hats. This is also (quasi-Pareto optimal. However, a tariff that protects only shoes and coats is not efficient but is quasi-Pareto optimalthere is no other tariff, providing each country with industrial production equal to $O M$, that will yield a higher joint income. Even though coat production is more expensive than hat production, coat production is South's most economic (least uneconomic) industry. A quasiPareto-optimal tariff is designed to permit each country to produce any specified level of industrial production in the cheapest way. It follows that genuine Pareto optimality must require choosing a quasi-Pareto-optimal tariff. ${ }^{27}$

It follows from the "rules" underlying CU's that neither country is permitted to produce a good that can be produced more cheaply in the other country. This may create problems, as can be seen in Figure $3 c$. Here South has an intra-union comparative disadvantage in its three cheapest industries-hats, shoes, and dresses - and hence cannot produce them in a CU with North. If these industries

\footnotetext{
${ }^{27}$ There will be a quasi-Pareto-optimal tariff corresponding to each pair of levels of industrial produc-
} tion. are protected at all, they will locate in lower-cost North. However, of those goods that South can produce, quasiPareto optimality requires that the cheapest are selected for protection. Thus the lowest cost industry in which South has an intra-union comparative advantage-ties-would be the first industry on South's list.

It follows from the discussion above that, under quasi-Pareto optimality, membership in a $\mathrm{CU}$ will result in a new hierarchy of industries for each country and, consequently, in new supply curves. The new hierarchy will include only industries in which the country has an intra-union comparative advantage. The ranking of these industries will remain unchanged, but each industry, if established at all, will operate at twice the planned pre-CU level of production, to supply the whole CU market.

If the distribution of income is left to market forces, the "cost" of each protected industry is shared equally by the two countries. Consequently, from each country's point of view, the cost of establishing an industry is reduced by onehalf. This raises an interesting point. Because half the cost of a country's uneconomic industry is paid by consumers in the partner country, there is a divergence between private (which in this case means "national") and social (meaning "CU") costs of industry. In other words, there are external diseconomies associated with industrialization. If each country ignores these diseconomies and determines its level of industrial production with regard to private cost considerations alone, then a quasi-Pareto-optimal tariff will produce results that are nonPareto optimal. We shall develop this point in the following section. 
PRODUCTION-CONSUMPTION LOCUS IN A CUSTOMS UNION

Corresponding to each country's new supply-of-industry curve is a new production-consumption locus. If South increases its level of industrial production, it moves out along its locus. But if industrial production increases in North, South's locus is shifted toward the origin.
South to buy no products from North, South retains the pre-CU option of producing at point $M$. Beyond point $M$, the new locus may lie wholly above the old one (as drawn in Figure 4); alternatively, the new locus may lie wholly below or may intersect the old locus. ${ }^{29}$

If North produces industrial goods, then South can no longer attain point $M$.

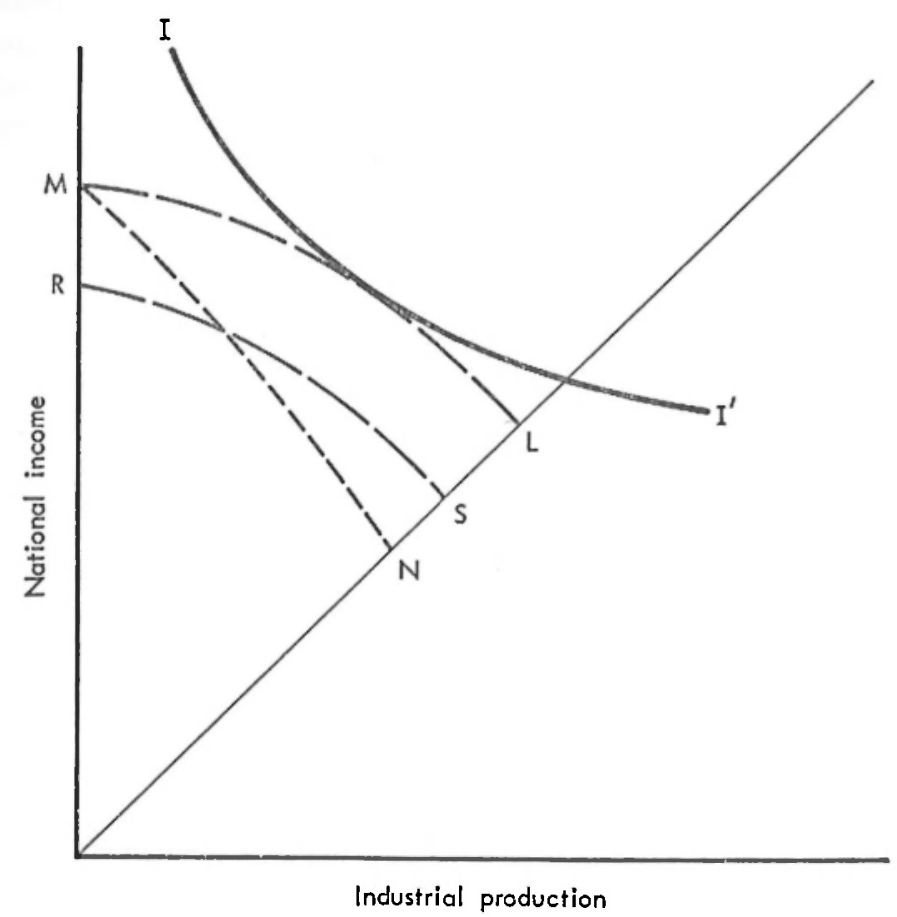

Fig. 4.-Impact of a customs union on the production-consumption locus

This is illustrated in Figure 4. South's preunion locus is $M N$. The new locus is $M L$, assuming there to be no industrial production in North. ${ }^{28}$ This new locus originates at point $M$ because, assuming

${ }^{28}$ With a $\mathrm{CU}$, the production-consumption locus is no longer constrained not to cross the $45^{\circ}$ ray from the origin. South's value of industrial production may exceed its income, if some of the industrial goods are sold in North. Similarly, if South buys uneconomic industrial goods from North, South may be unable to reach the $45^{\circ}$ ray. Whether the locus falls short of or crosses the $45^{\circ}$ ray depends on how the CU affects South's terms of trade.
South's locus then shifts down by an amount equal to South's share of the difference between North's cost of produc-

${ }^{29}$ The fact that South's industrial production is partly supported by North's consumers tends to make South's new locus lie outside the old one (as a given industry costs South only one-half the preunion price). In addition, specialization on the lowest cost industries (if South has an intra-union comparative advantage in these industries) will tend to make South's new locus lie above the old one. The new locus may lie below the old one only if South has an intra-union comparative disadvantage in its cheapest industries and must turn to higher-cost industries in order to have an industrial sector at all. 
tion and world-market prices of all goods produced by North (shown in Figure 4 by the distance $M R$ ). ${ }^{30}$ Thus the position of South's locus will depend on North's level of industrial production and on how uneconomic this production is. ${ }^{31}$

\section{PARETO OPTIMALITY}

Let us define a Pareto-optimal tariff as a set of common external tariff rates with the following property: Given some rule for redistributing income, the tariff results in levels of industrial production in each country such that neither country's welfare can be raised without a reduction in the other country's welfare.

If the distribution of income is left to market forces, then each country will equate the marginal gain from industrial production to the marginal private cost, and a Pareto-optimal tariff will not be chosen. This can be seen as follows: An increase in industrial production in South will, up to a point, move South to a higher social indifference curve, as can be seen in Figure 4. But, for the reasons outlined above, an increase in North's industrial output will force South onto a lower production-consumption locus and, consequently, a lower indifference curve. By selecting a tariff that puts each country at the point at which an indifference curve is tangent to the production-consumption locus, both countries will be ignoring external diseconomies of industrialization. Although a unilateral reduction in industrial production will make either country worse off, a negotiated joint reduction in industrial production

${ }^{30}$ In other words, because South buys North's uneconomic goods at a price above the world market price, South's terms of trade deteriorate.

${ }^{31}$ If North has an intra-union comparative advantage in all industries (and South consequently a comparative advantage only in corn production), t ten South's new locus will consist simply of one point on the vertical axis. will make both countries better off. ${ }^{32}$ Thus, the result is not Pareto optimal.

A genuine Pareto-optimal solution requires each country to take account of external diseconomies generated by its industrial production. One way to do this is to require each country to pay full income compensation to its partner for the relatively high-cost industrial goods sold in the partner's market. We can then construct a new curve-call it an "adjusted production-consumption locus." Each point on South's adjusted locus shows the income and industrial production available to South, after deducting from South's income an amount equal to the increased cost imposed on North. South pays no compensation if it has no industrial production, so the adjusted locus, $M L$, originates at point $M$ (Figure 5 ) as did the old locus, $M N$. But as South's industrial output expands, the required compensation increases, so that the divergence between the adjusted locus and the unadjusted locus widens.

South can select any point on its adjusted locus without affecting North's welfare. In Figure 5, South would choose point $P$, which represents a tangency solution. South can do no better, and North is indifferent between this point and any other point on the same locus. There is a comparable point on North's adjusted locus. The two countries can be maintained at this pair of points by a Pareto-optimal tariff. ${ }^{33}$

Although the present construct leads to a unique Pareto-optimal solution, other Pareto-optimal situations exist. To demonstrate this, modify the rules

32 This is a common characteristic of two-personnon-zero sum games; an interesting parallel is the issue of disarmament.

33 We wish to emphasize that this tariff is not necessarily Pareto optimal (as defined above) with any other set of rules for distributing income between the countries. 
as follows: Each year, North makes some specified lump-sum income payment to South. Then South's locus shifts up, and North's locus shifts down. Unless the planners' demand for industry is wholly income inelastic, each country will choose a new level of industrial production, and there will be a new Paretooptimal tariff. ${ }^{\mathbf{3 4}}$

Each country's adjusted productionconsumption locus will lie outside its pre$\mathrm{CU}$ locus if the country has an intraunion comparative advantage in its lowest cost industries (so that the cost of a given level of industrial production is reduced). On the other hand, the adjusted locus will lie inside the pre-CU locus if the country has a comparative disadvantage in its cheapest industries (so that it is forced to move up the hierarchy of industries). Another possibility is that a country's adjusted locus cuts the preunion locus. Then some levels of protection will be cheaper but other levels more costly, compared with the pre-CU situation.

If, at the relevant ${ }^{35}$ part of the curve, each country's adjusted productionconsumption locus lies outside its preunion locus, then a CU necessarily permits both countries to gain. ${ }^{36}$ Each country can produce at its preunion level of industrial output and will have resources to spare. But if the relevant part of either country's adjusted locus lies inside the pre-CU locus, that country is made worse off by the CU - at least under the tariff and set of rules discussed in this section. ${ }^{37}$ In this case it may be possible

${ }^{34} \mathrm{~A}$ Pareto-optimal tariff is necessarily quasiPareto optinal, but the converse does not hold. Also, a Pareto-optimal tariff need not be efficient, nor need an efficient tariff result in Pareto optimality.

${ }^{35}$ This is admittedly a question-begging word.

${ }^{36}$ That is, if the distributive rules and the tariff are chosen as outlined here. for the more favored country to offer sufficient additional compensation to the less favored country in order to leave both countries better off. If this fails, then departure from the principle of free trade within the $\mathrm{CU}$ may still permit gains to both countries. We shall take up these possibilities in the two following sections.

\section{COMPENSATION}

In Figure 6, South's adjusted production-consumption locus is $M L$, compared with a pre-CU locus of $M N$. South is therefore forced onto a lower indifference curve in the CU. The amount of additional income compensation necessary to make South at least as well off with as without the union is shown in Figure 6 as $E F$. If North gains more than this amount, North will be able to compensate South fully and still be better off. ${ }^{38}$ In this case, a CU is potentially beneficial. It is possible, however, that North will not gain enough to pay sufficient compensation to South, even if North's income gains exceed South's income losses. ${ }^{39}$

\section{PARTIAL CUSTOMS UNIONS}

Allowing protection within a CU may increase the gains obtainable from one. A partial $\mathrm{CU}$ can be defined as an ar-

${ }^{37}$ One might think that a readjustment of exchange rates would enable both countries to specialize. But remember that each country produces corn for export; exchange rates are determined by the average cost of producing corn.

${ }^{38}$ This transfer of income will shift South's locus out and North's locus in, so that a new tariff will be chosen.

${ }^{39}$ If South loses industry as well as (or instead of) income, the amount of income compensation South requires depends on the shape of South's indifference curves, which bears no relation to the amount of North's income gains. For many developing nations, the indifference curves may be sufficiently steep in the relevant range that income compensation alone will not work. 


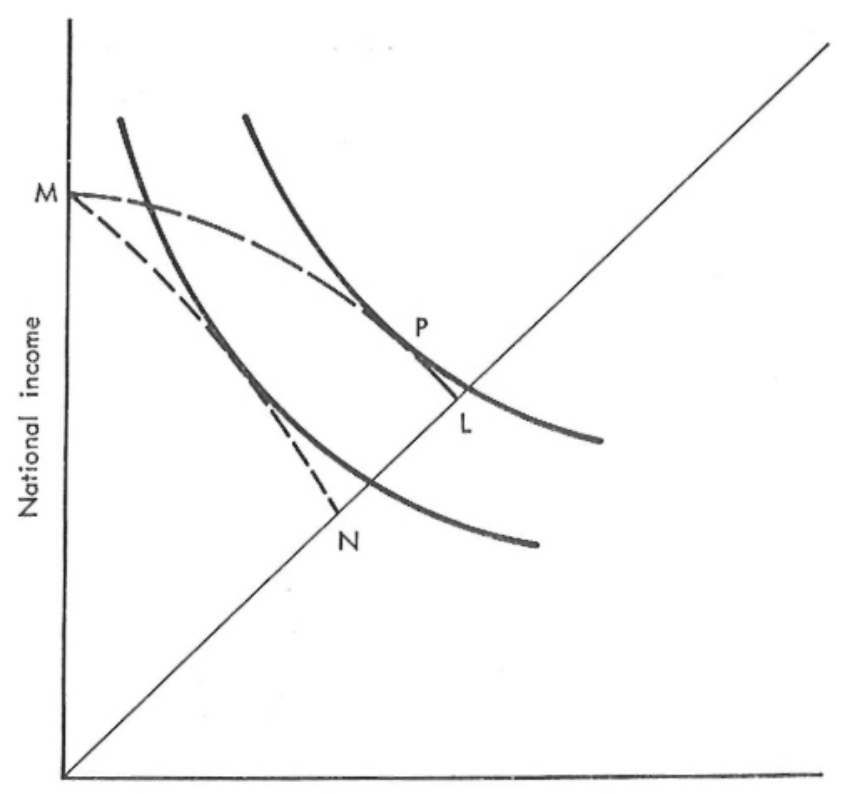

Industrial production

F1G. 5.-The adjusted production-consumption locus

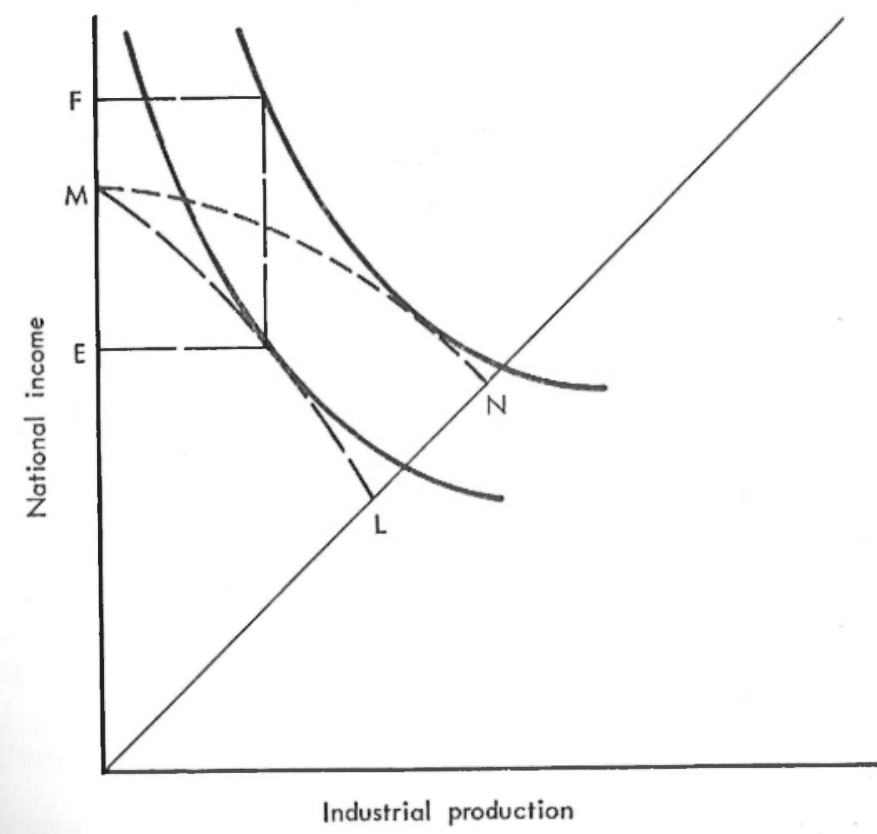

Fig. 6.-Compensation 
rangement whereby two or more countries have a common external tariff-but not internal free trade. For example, some of South's manufactured goods could be protected against North's industry. South would have unrestricted access to North's market, but the reverse would not hold.

To take a simple but extreme case, suppose South is allowed to establish all the industries on its list, even though these industries are more economic in North. Assume also that North produces other industrial goods and sells them in the combined $\mathrm{CU}$ market, compensating South for the higher cost of these goods, compared to world-market prices. South is no worse off (indeed, South has not been affected by the union); and North gains, since the total cost of producing a given amount of industry in North is less than before the $\mathrm{CU}$ was formed.

It might even be desirable to allow South to export some of its higher-cost industrial goods to North. Suppose for example that, although South's most efficient industry can produce more cheaply in North, it nevertheless ranks far down on North's list, so that North chooses not to establish this industry. Then South can establish the industry, supply the combined market, and com1 pensate North. In this case, North is clearly no worse off and South gains by being able to specialize on a low-cost industry instead of having to also develop a higher cost industry to serve the local market. These arrangements insure that each country's adjusted production-consumption locus lies outside the pre-CU locus.

\section{SUBSIDIES}

In the analysis above, we have ruled out export subsidies. In principle, sub- sidizing exports offers greater scope for expanding the industrial sector than does a CU. If subsidization opened up world markets to a less developed country, the cost of protection would be lower still than in a CU. Subsidizing exports would permit more effective specialization. But "real-world" complications are such that an industrial sector based on production for export may be exceedingly difficult to establish and maintain. Not only are the industrial markets of advanced economies difficult to enter economically, but obtaining the necessary political co-operation would be very unlikely. ${ }^{40}$

But subsidization can be used wilhin a CU. For example, each government can provide a sufficient subsidy to firms otherwise unable to compete in order to enable these firms to sell in the CU market at world-market prices. All intraunion trade then takes place at world prices, the purchasing country suffers no loss, and the producing country bears the entire cost of its industry. In terms of national accounts, a system of subsidies is equivalent to compensation. But with subsidization, compensation is automatic, and the prices of industrial goods within the CU remain equal to the prices of comparable imports.

\section{COMPARISON WITH EXISTING THEORY}

It is of some interest to compare our results with those obtained by Viner and other $\mathrm{CU}$ theorists. In the Vinerian world, trade creation is good and trade diversion bad; a $\mathrm{CU}$ is more likely to result in a net welfare gain "the greater is the degree of overlapping between the class of commodities produced under

${ }^{40}$ Harry G. Johnson has suggested to us that general production subsidies could be used to evade the international rules against export subsidies. 
tariff protection in the two countries." With substantial overlapping, trade creation is likely to "outweigh" trade diversion. If, however, the two countries are complementary, different industries are likely to be protected in each country, and a $\mathrm{CU}$ will tend on balance to be trade-diverting, with the loss in efficiency (and hence in welfare) that Vinerian theory associates with this result. ${ }^{2}$

Our model differs in two respects. First, we allow a possible preference for industry; second, we regard the tariff as a policy instrument rather than an exogenous variable. The gains from a $\mathrm{CU}$ depend on what happens to both income and industrial output; this, in turn, de-

${ }^{41}$ R. G. Lipsey, "The Theory of Customs Unions," op. cit., p. 499. Lipsey goes on to qualify these results by considering intercommodity substitution. He maintains that, given a sufficiently inappropriate set of revenue tariffs, prior to the formation of the $\mathrm{CU}$, trade diversion can raise welfare. (See the two papers by Lipsey cited above.) For a critique of Lipsey's analysis, see our paper described in n. 4

${ }^{42}$ Given that trade creation predominates, the magnitude of the gain will be greater (according to existing theory) the more complementary the two economies are-that is, the greater the difference in their costs of producing industrial goods. (See Lipsey, "The Theory of Customs Unions," op. cit.; H. Makower and G. Morton, "A Contribution towards a Theory of Customs Unions," Economic Journal, LXII [March, 1953], 33-49; H. G. Johnson, Trade and Economic Growth [Cambridge, Mass.: Harvard University Press, 1962], p. 44.) But two situations must be distinguished. First, perhaps North has a substantial comparative advantage in industrial production generally, so that appreciable gains result from shifting production from South to North. In this case, the gains are simply a reflection of the highly uneconomic character of industrial production in South. But one is led to ask whether, in practice, South will be prepared to yield its protected industries to North. A quite different situation is one in which the industries on the lower half of North's supply curve are quite different from the industries on the lower half of South's curve. $R_{\text {at }}$ this is a peculiar set of circumstances. If fwo countries produce identically the same batch of goods, one would be surprised to find grossly different structures of costs in producing these goods. pends on the common external tariff that is chosen. A CU involves the establishment of conditions under which the tariff can be used more effectively. Our conclusions have been based on the assumption that an appropriate tariff is always chosen. The emphasis is, in other words, on the potential gains. In Viner's world, the choice of tariff is sidestepped; it is often implied that a non-optimal tariff policy is adopted. ${ }^{43}$

In our model, either trade creation or trade diversion can be good and either can be bad. With a trade-diversion case, each economy expands its industrial production to supply the other's market. While this may reduce each economy's national income, industrial production is expanded. Without knowing more about the countries' indifference curves, one cannot say whether this raises or lowers welfare. Similarly, consider trade creation. Say that North is a lower-cost producer than South for all industrial products, so that with a $\mathrm{CU}$, production shifts from South to North. Although South now pays less for its industrial goods, its industrial sector has been lost in the bargain. Is South necessarily better off? Again, one cannot answer without some knowledge of South's preferences. If either country loses income or industry, it must gain enough of the other to be adequately compensated.

The potential gain from a $\mathrm{CU}$ will be larger if: (1) There is a steeply rising marginal cost of protection in the two countries, (2) the countries have a strong preference for industry, (3) the countries are complementary, and (4) neither country dominates the other in industrial

${ }^{43}$ To be fair to Viner we should point out that GATT rules constrain the member countries' ability to select an optimal tariff. Viner's analysis is, of course, based on an entirely different conception of tariff policy. 
production generally. ${ }^{44}$ Even if the fourth condition does not obtain, gains can still, in principle, be obtained from forming a partial union or from some other device that interferes with free trade within the $\mathrm{CU}$. The impact of a CU will depend on the precise rules under which it is formed -the rules governing the location of industry, intra-union trade, and compensation. In general, the greater the flexibility of these rules, the larger are the potential gains.

But the real moral goes beyond these considerations. Economic integration may enable two or more economies to protect a given amount of industry at a lower real cost. Whether or not this result is effected depends on the prefer-

44 That is, neither country has an intra-union comparative advantage in all or most industries (the case shown in Fig. 3c). ences of the participants and, much more important, on the degree to which they co-operate. In many cases detailed cooperative effort will be needed if one country is not to lose more in the industry dimension than it gains in the income dimension or, worse still, to lose in both dimensions. A CU may make it technically possible for both countries to gain; a $\mathrm{CU}$ combined with subsidization or comparable policies will guarantee a potential gain. But neither set of policies will insure that the gains are realized.

In ideal cases there will be no conflict. By following their own bents, each country will gain. Even if no explicit compensation is granted, gains may be roughly distributed to each. But in other cases not only will explicit compensation agreements be required but there will have to be detailed agreement on intra-union division of industry. 